\title{
Evaluation of ad libitum acidified milk replacer programs for dairy calves
}

\author{
T. M. Hill, ${ }^{1}$ H. G. Bateman II, J. M. Aldrich, J. D. Quigley, and R. L. Schlotterbeck \\ Nurture Research Center, Provimi North America, Brookville, OH 45309
}

\begin{abstract}
Due to renewed interest in feeding acidified milk replacer (MR) for ad libitum consumption within North America, two 112-d trials were conducted using Holstein calves obtained from one dairy farm at 2 to $3 \mathrm{~d}$ of age. In trial 1, a $27 \%$ crude protein (whey protein), $17 \%$ fat MR powder was reconstituted with water to $14 \%$ solids and fed at $0.66 \mathrm{~kg}$ of dry matter $(\mathrm{DM})$ per day for $42 \mathrm{~d}(\mathrm{CON})$ or acidified to $\mathrm{pH} 4.2$ using citric acid and offered $24 \mathrm{~h} / \mathrm{d}$ for $\mathrm{d} 0$ to 35 , then switched to $0.66 \mathrm{~kg}$ of DM without acid per $\mathrm{d}$ for $7 \mathrm{~d}$ (A4). In trial 2, the same MR was fed as CON, ad libitum $\mathrm{pH} 5.2 \mathrm{MR}$ offered from 0600 to $0800 \mathrm{~h}$ and 1600 to $1800 \mathrm{~h}$ for $\mathrm{d} 0$ to 21 (R5), ad libitum pH $5.2 \mathrm{MR}$ offered $24 \mathrm{~h} / \mathrm{d}$ for d 0 to 35 (A5), and ad libitum pH $4.2 \mathrm{MR}$ offered $24 \mathrm{~h} / \mathrm{d}$ for d 0 to 35 (A4). After the ad libitum period, calves on R5, A5, and A4 were switched to CON until d 42. Growth measures were made until d 112 in each trial. Data from each trial were analyzed as a completely randomized design with repeated measurements over time using an autoregressive type 1 covariance structure when appropriate. In each trial, calves fed CON had lower average daily gain (ADG) from 0 to $42 \mathrm{~d}$ and greater ADG from 42 to $56 \mathrm{~d}$ than calves fed the other treatments. In both trials, ADG from 0 to $56 \mathrm{~d}$ and 56 to $112 \mathrm{~d}$ were not greater for A4 or A5 versus CON. From 56 to 112 d in trial 2, ADG was greater for R5 versus A5. Some calves completely rejected the $\mathrm{MR}$ at $\mathrm{pH}$ 4.2. Calves consumed more of the MR at $\mathrm{pH} 5.2$ than 4.2. Calves fed A4 in trial 1 and treatments A5 and A4 in trial 2 consumed $>95 \%$ of their MR between 0600 to $0800 \mathrm{~h}$ and 1600 to $1800 \mathrm{~h}$. Time spent standing did not differ by treatment in trial 1 and increased from 312 to $332 \mathrm{~min} / \mathrm{d}$ from d 6 to 56 . Under the conditions of these trials, results to $112 \mathrm{~d}$ showed no advantage to feeding calves MR acidified to $\mathrm{pH} 4.2$ or 5.2 ad libitum from 0 to $35 \mathrm{~d}$ with gradually weaning by $42 \mathrm{~d}$ compared with calves fed the control MR fed at $0.66 \mathrm{~kg}$ of DM/d. Additionally, when calves were fed MR ad libitum, they consumed $>95 \%$ of the
\end{abstract}

Received September 6, 2012.

Accepted January 9, 2013.

${ }^{1}$ Corresponding author: mhill@provimi-na.com
MR between 0600 to $0800 \mathrm{~h}$ and 1600 to $1800 \mathrm{~h}$ and standing behavior was not greatly affected.

Key words: acidified milk replacer, feeding rate, calf, behavior

\section{INTRODUCTION}

Farm advisors in Canada and the United States have proposed group housing of calves fed acidified milk or milk replacer (MR) as a means to increase the ADG of calves in a healthy and humane environment while reducing labor requirements (Anderson, 2006; Conway, 2011). A challenge with feeding milk or MR for ad libitum consumption without using a computer feeder is keeping the milk available at all times while minimizing bacterial growth and contamination. This has been addressed by feeding calves ad libitum milk, but only for $4 \mathrm{~h} / \mathrm{d}$ in $2 \mathrm{~h}$ periods in the a.m. and p.m., which supported similar milk intake, starter intake, and ADG to calves offered milk for $24 \mathrm{~h} / \mathrm{d}$ (von Keyserlingk et al., 2006).

Several researchers have evaluated the effect of ad libitum MR feeding on intake and growth of calves (Thickett et al., 1983; Nocek and Braund, 1986; Fallon and Harte, 1988; Richard et al., 1988; Hepola et al., 2008). Where postweaning measurements were made (Nocek and Braund, 1986), calves fed the ad libitum plane of nutrition had greater ADG preweaning, but less ADG postweaning compared with calves fed conventionally (approximately $440 \mathrm{~g}$ of $\mathrm{DM} / \mathrm{d}$ ). This pattern of growth is true in calves fed low versus high planes of both milk (Bar-Peled et al., 1997; Jasper and Weary, 2002) and MR (Cowles et al., 2006; Hill et al., 2006) in non-ad libitum situations. The reduced ADG in postweaned calves has been overcome with gradual weaning over approximately 21 d (Khan et al., 2007; Hill et al., 2007, 2012; Sweeney et al., 2010).

It is difficult to assess intake of starter and feed efficiency in groups of calves compared with individually housed calves. However, it has been reported that calves fed large amounts of milk or MR and managed either as individuals or groups did not differ in MR intake, starter intake, or ADG (Nocek and Braund, 1986; Richard et al., 1988; De Paula Vieira et al., 2010), allowing research with calves in individual pens to be used. 
Choice of acids used to acidify MR is also in question; several studies have used formic acid to reduce MR $\mathrm{pH}$ (Bush and Nicholson, 1987; Hepola et al., 2008). However, acidifying MR with formic acid is not approved by the Food and Drug Administration. Bush and Nicholson (1987) reported that acidifying MR with formic acid reduced MR intake compared with propionic acid, formaldehyde, or unacidified control MR. Most commercial applications in the United States rely on citric acid as acidifying agent; however, few data are available in the literature that report the use of this acid as an acidifying agent. Final $\mathrm{pH}$ of the solution may also affect voluntary intake and subsequent performance. Studies have reported many different final MR pH: 5.6 (Thickett et al., 1983), 4.5 or 5.0 (Hepola et al., 2008), and 5.3 or 5.7 (Bush and Nicholson, 1987).

The aim of trial 1 was to evaluate an MR acidified to $\mathrm{pH} 4.2$ and offered to calves ad libitum in nipple pails. Our hypothesis was that calves fed ad libitum would gain more BW preweaning, but less postweaning. Based on the results on trial 1 , the aim of trial 2 was to reevaluate ad libitum-fed MR acidified to a different $\mathrm{pH}$ (4.2 and 5.2), for different durations over a day (4 and $24 \mathrm{~h}$ availabilities/d), and total number of days (21 and $35 \mathrm{~d})$. Our hypothesis was that calves fed a high $\mathrm{pH}$ MR would not reject it and would have greater intake. Also, calves with 4-h feed availability per day would perform equally to calves with 24 -h feed availability. Finally, calves fed ad libitum for $21 \mathrm{~d}$ would gain as much BW as calves fed ad libitum for $35 \mathrm{~d}$.

\section{MATERIALS AND METHODS}

\section{Trial 1}

All calves were cared for as described in the Guide for the Care and Use of Agricultural Animals in Agricultural Research and Teaching (FASS, 2010). Holstein bull calves ( 2 to $5 \mathrm{~d}$ of age, $\mathrm{n}=20$ ) from a single dairy farm were transported $3.5 \mathrm{~h}$ to the Nurture Research Center in southwest Ohio and received at $\sim 1100 \mathrm{~h}$. Calves were randomly assigned to treatments on ar- rival and offered their first MR at $1600 \mathrm{~h}$. At $1100 \mathrm{~h}$ the day after arrival, the calves were weighed (initial BW), blood was sampled from the jugular vein, serum was harvested, and serum protein concentration was immediately measured using an optical refractometer (Atago U.S.A. Inc., Bellevue, WA).

A $27 \% \mathrm{CP}$ (whey protein), $17 \%$ fat MR powder (DM basis; Table 1) was reconstituted with warm water to $14 \%$ solids. The final solution temperature was 45 to $46^{\circ} \mathrm{C}$. Control calves $(\mathbf{C O N})$ were fed $0.68 \mathrm{~kg}$ (as-fed basis) of powder via this solution daily in 2 equal meals at 0600 and $1600 \mathrm{~h}$. A second group of calves were fed the same MR solution acidified to $\mathrm{pH} 4.2$ (A4). The liquid solution was cooled to $32^{\circ} \mathrm{C}$ and citric acid powder was stirred in slowly to reach the target $\mathrm{pH}$. The acidified MR was placed in a covered container at $21^{\circ} \mathrm{C}$ for $24 \mathrm{~h}$ before being fed. It was agitated by hand with a whisk for approximately $60 \mathrm{~s}$ at 0800,1200 , and 1800 $\mathrm{h}$ immediately before feeding. To feed, the reconstituted $\mathrm{MR}$ was reheated to 45 to $46^{\circ} \mathrm{C}$ in a double water bath. All calves were fed MR via a nipple pail. Refused MR was weighed, and new MR fed was weighed at 0600, $0800,1200,1600$, and $1800 \mathrm{~h}$ daily on d 0 to 35 for the ad libitum MR portion of the trial. The temperature of the MR fed and the MR unconsumed was measured. From d 36 to 42 , all calves were fed the MR without acidification. Calves were completely weaned by d 42 by only feeding MR at $0600 \mathrm{~h}$ on d 40, 41, and 42 . Calves were fed a textured starter $(20 \% \mathrm{CP}$ on DM basis; $37 \%$ whole corn, $35 \%$ supplement pellet, $25 \%$ whole oats, $3 \%$ molasses; supplement pellet contained $66 \%$ soybean meal, $22 \%$ wheat middlings, $9 \%$ minerals and vitamins, $3 \%$ molasses; Table 1). Calves were fed starter and water ad libitum. Newly fed and refused starter was weighed daily.

The MR powder was sampled daily at the a.m. feeding and composited. Every second bag $(22.7 \mathrm{~kg})$ of starter feed was sampled and composited. Composites of feeds were analyzed (AOAC International, 2000) for DM (oven method 930.15), fat (alkaline treatment with Röse-Gottlieb method 932.06 for MR; diethyl ether extraction method 2003.05 for starters and hay), and

Table 1. Nutrient analysis (\% of DM, unless otherwise noted) of feeds used in trials 1 and 2

\begin{tabular}{|c|c|c|c|c|c|c|}
\hline \multirow[b]{2}{*}{ Nutrient } & \multicolumn{2}{|c|}{ Milk replacer } & \multicolumn{2}{|c|}{ Starter } & \multicolumn{2}{|c|}{ Hay } \\
\hline & Trial 1 & Trial 2 & Trial 1 & Trial 2 & Trial 1 & Trial 2 \\
\hline DM, \% & 96.2 & 96.2 & 87.3 & 87.6 & 88.5 & 88.5 \\
\hline $\mathrm{CP}$ & 27.3 & 27.3 & 20.7 & 20.6 & 14.9 & 14.7 \\
\hline Fat & 18.1 & 18.0 & 3.9 & 3.7 & 3.9 & 3.7 \\
\hline $\mathrm{ADF}$ & - & - & 5.9 & 6.1 & 32.5 & 33.9 \\
\hline NDF & - & - & 11.9 & 12.3 & 51.3 & 53.4 \\
\hline $\mathrm{Ca}$ & 0.85 & 0.84 & 0.81 & 0.84 & 0.71 & 0.69 \\
\hline $\mathrm{P}$ & 0.63 & 0.63 & 0.62 & 0.61 & 0.28 & 0.25 \\
\hline
\end{tabular}


Ca and P (dry ashing, acid digestion, analysis by ICP, method 985.01). Additionally, the starter (and hay in trial 1a and 2a) was analyzed for NDF with ash by the procedure of Van Soest et al. (1991) without sodium sulfite or $\alpha$-amylase, and ADF with ash (Robertson and Van Soest, 1981).

Calves were weighed every $7 \mathrm{~d}$ until the end of the trial (d 56). Feed offered and refused were weighed daily. Fecal scores were assigned daily based on a 1 to 5 system $(1=$ normal, thick in consistency; $2=$ normal, but less thick; $3=$ abnormally thin but not watery; 4 $=$ watery; $5=$ watery with abnormal coloring; modified from Kertz and Chester-Jones, 2004). Hip widths were measured with a caliper, and BCS of calves were measured during the initial (d 0) measurement period and every $14 \mathrm{~d}$ thereafter. A 1 to 5 system using 0.25 unit increments, with $1=$ emaciated and $5=$ obese, was used for BCS (Wildman et al., 1982). Scores were based on changes around the vertical and transverse processes of the spine, as palpated by one experienced technician, and ranged from 1.5 to 3.5. The trial was conducted during the months of December through February. The average ambient temperature inside the barn during the trial was $1^{\circ} \mathrm{C}$ and ranged from -15 to $15^{\circ} \mathrm{C}$, based on hourly measurements. The average humidity was $78 \%$ and ranged from 44 to $100 \%$.

Standing and lying behavior was recorded via an electronic data logger (HOBO Pendant G Acceleration Data Logger, Onset Computer Corporation, Pocasset, MA) attached to the medial side of the right rear leg of 5 calves randomly selected per treatment. A plastic identification bracelet (Nasco, Fort Atkinson, WI) was attached to the leg and the logger was taped (Vet Wrap Co-Flex, Andover Coated Products Inc., Salisbury, MA) to the bracelet. Tape was then applied over the logger and bracelet. The logger was attached on $\mathrm{d} 4$ and set to record data every 5 min from d 6 to 56 . Data were managed with adjustments for a 5-min recording interval and categorized either as standing or lying similar to the description in Ito et al. (2009).

Calves were housed in $1.2 \times 2.4 \mathrm{~m}$ individual pens within a curtain sidewall barn with no added heat. The pens were bedded with long straw. Calves received an intranasal tissue sensitive respiratory disease vaccine (TSV-2, Pfizer, Exton, PA) and subcutaneous injections of vitamins A, D, E (Vital E - A + D, ScheringPlough Animal Health, Union, NJ), and Se (MU-SE, Schering-Plough Animal Health) upon arrival. Calves received an intramuscular respiratory disease vaccine (Bovashield Gold 5, Pfizer) at d 7 and again at d 28. At d 14 and 49 calves received an intramuscular vaccine for types $\mathrm{C}$ and D Clostridium (Vision 7 with Spur, Intervet Inc., Millsboro, DE) and a subcutane- ous Clostridium perfringens type A toxoid (Novartis, Larchwood, IA). A Pasteurella vaccine (Presponse HM, Fort Dodge, Fort Dodge, IA) was administered intramuscularly on d 35 and 49 . Calves were castrated and dehorned at $39 \mathrm{~d}$ of age. Calves that scoured (fecal scores $>2$ ) were treated with oral electrolytes. Antibiotics were not used because the major historical causes of diarrhea in this unit are rotavirus or Cryptosporidium parvum. Additionally, the duration of diarrhea in this trial was short and antibiotics were not necessary. No calves were treated for other reasons or received other health-related products.

Data were analyzed using the MIXED procedure of SAS (Version 8, SAS Institute Inc., Cary, NC) as a completely randomized design. The statistical model used was

$$
\mathrm{Y}_{\mathrm{ijkl}}=\mu+\mathrm{T}_{\mathrm{i}}+\mathrm{w}_{\mathrm{j}}+\mathrm{Tw}_{\mathrm{ij}}+\mathrm{C}_{\mathrm{k}}\left(\mathrm{T}_{\mathrm{i}}\right)+\varepsilon_{\mathrm{ijkl}},
$$

where $Y_{\mathrm{ijkl}}$ is the observed measurement; $\mu$ represents the overall population mean; $T_{i}$ is the fixed effect of treatment $\mathrm{i} ; \mathrm{w}_{\mathrm{j}}$ is the random effect of week $\mathrm{j} ; \mathrm{Tw}_{\mathrm{ij}}$ is the interaction of treatment $\mathrm{i}$ and week $\mathrm{j} ; \mathrm{C}_{\mathrm{k}}\left(\mathrm{T}_{\mathrm{i}}\right)$ is the random effect of calf $\mathrm{k}$ nested within treatment $\mathrm{i}$ that was used to test effect of treatment; and $\varepsilon_{\mathrm{ijk}}$ is the residual assumed to be normally distributed with mean zero. Week was modeled as a repeated measurement using an autoregressive type 1 covariance structure.

\section{Trial 1a}

To assess the effect of $2 \mathrm{MR}$ programs on subsequent growth postweaning, calves from trial 1 were moved to multi-calf pens on d 56 with calves grouped 4 per pen. An equal number of calves from each MR treatment were housed per pen; this precluded estimating DM intake by treatment. The diet was a mixture of the same starter used in trial 1 with $5 \%$ chopped grass hay. This diet and water were offered ad libitum. Feed refused and new feed offered to pens were weighed daily.

Pens provided $6.5 \mathrm{~m}^{2}$ of outside space and $1.35 \mathrm{~m}^{2}$ of inside space per calf. The inside space was bedded with long straw and had no added heat. No animals were sick or were treated for sicknesses or vaccinated during the 56-d trial. Calves were weighed, hip widths were measured, and body condition was scored initially and every $28 \mathrm{~d}$ thereafter. Feed offered and refused was weighed daily. The trial lasted $56 \mathrm{~d}$ and was conducted during the months of February through April. Average ambient temperature during the trial was $11^{\circ} \mathrm{C}$ and ranged from -8 to $31^{\circ} \mathrm{C}$, based on hourly measurements. Average humidity was $67 \%$ and ranged from 20 to $96 \%$. Calf was the experimental unit. Growth data 
were analyzed using the model used in trial 1 . Week was replaced with a 28 -d period.

\section{Trial 2}

Holstein bull calves ( 2 to $5 \mathrm{~d}$ of age, $\mathrm{n}=48$ ) from a single dairy farm were transported $3.5 \mathrm{~h}$ to the Nurture Research Center in southwest $\mathrm{OH}$ and were received at $\sim 1100 \mathrm{~h}$. treatments were randomly assigned and fed as in trial 1. Calves were managed and housed as in trial 1 . The trial lasted $56 \mathrm{~d}$ and was conducted during the months of February through March. Average ambient temperature inside the barn during the trial was $7^{\circ} \mathrm{C}$ and ranged from -11 to $31^{\circ} \mathrm{C}$, based on hourly measurements. Average humidity was $72 \%$ and ranged from 33 to $96 \%$.

A $27 \% \mathrm{CP}$ (whey protein), $17 \%$ fat MR powder (DM basis; Table 1) was reconstituted with warm water to $14 \%$ solids. The final solution was heated to 45 to $46^{\circ} \mathrm{C}$. Calves were fed 4 different MR treatments: control-fed at $0.68 \mathrm{~kg}$ of as-fed powder $/ \mathrm{d}$, in 2 equal meals at 0600 and $1600 \mathrm{~h}(\mathbf{C O N})$; ad libitum-fed pH 5.2 MR offered at 0600 and $0800 \mathrm{~h}$ and 1600 and $1800 \mathrm{~h}$ for d 0 to 21 (R5); ad libitum-fed pH 5.2 MR offered $24 \mathrm{~h} / \mathrm{d}$ for d 0 to 35 (A5); ad libitum-fed pH $4.2 \mathrm{MR}$ offered $24 \mathrm{~h} / \mathrm{d}$ for d 0 to 35 (A4). Reconstituted MR for R5 calves was acidified immediately after reconstitution to $\mathrm{pH}$ 5.2 and fed within the 2 -h periods in the a.m. and p.m.

Table 2. Performance of calves fed a control milk replacer at a fixed rate (CON) or a milk replacer acidified to $\mathrm{pH} 4.2$ fed ad libitum (A4) in trial 1

\begin{tabular}{|c|c|c|c|c|}
\hline Item & $\mathrm{CON}$ & A4 & SEM & $P$-value \\
\hline Calves, no. & 10 & 9 & - & - \\
\hline Initial serum protein, $\mathrm{mg} / \mathrm{dL}$ & 5.2 & 5.5 & 0.17 & 0.32 \\
\hline Initial BW, kg & 45.9 & 42.6 & 1.49 & 0.12 \\
\hline \multicolumn{5}{|l|}{$\mathrm{ADG}, \mathrm{kg} / \mathrm{d}$} \\
\hline 0 to $42 \mathrm{~d}$ & 0.589 & 0.700 & 0.0309 & 0.02 \\
\hline 42 to $56 \mathrm{~d}$ & 0.754 & 0.680 & 0.0305 & 0.05 \\
\hline 0 to $56 \mathrm{~d}$ & 0.630 & 0.695 & 0.0309 & 0.09 \\
\hline \multicolumn{5}{|l|}{ Milk replacer intake $^{1}$} \\
\hline $\mathrm{kg}$ of $\mathrm{DM} / \mathrm{d}, 0$ to $42 \mathrm{~d}$ & 0.632 & 0.915 & 0.1103 & 0.01 \\
\hline Total $\mathrm{kg}$ of DM, 0 to $42 \mathrm{~d}$ & 26.6 & 38.5 & 4.64 & 0.01 \\
\hline \multicolumn{5}{|l|}{ Starter intake, $\mathrm{kg}$ of $\mathrm{DM} / \mathrm{d}$} \\
\hline 0 to $42 \mathrm{~d}$ & 0.357 & 0.286 & 0.0390 & 0.20 \\
\hline 42 to $56 \mathrm{~d}$ & 1.794 & 1.849 & 0.1242 & 0.75 \\
\hline 0 to $56 \mathrm{~d}$ & 0.717 & 0.677 & 0.0564 & 0.62 \\
\hline \multicolumn{5}{|l|}{ Feed efficiency, gain/feed } \\
\hline 0 to $42 \mathrm{~d}$ & 0.595 & 0.583 & 0.0529 & 0.75 \\
\hline 42 to $56 \mathrm{~d}$ & 0.420 & 0.368 & 0.0303 & 0.04 \\
\hline 0 to $56 \mathrm{~d}$ & 0.529 & 0.509 & 0.0308 & 0.13 \\
\hline \multicolumn{5}{|l|}{ Medical days, no. } \\
\hline 0 to $42 \mathrm{~d}$ & 2.1 & 2.6 & 0.48 & 0.47 \\
\hline 42 to $56 \mathrm{~d}$ & 0.3 & 0.2 & 0.14 & 0.62 \\
\hline 0 to $56 \mathrm{~d}$ & 2.4 & 2.8 & 0.50 & 0.57 \\
\hline \multicolumn{5}{|l|}{ Fecal score $^{2}$} \\
\hline 0 to $42 \mathrm{~d}$ & 1.9 & 1.9 & 0.03 & 0.26 \\
\hline 42 to $56 \mathrm{~d}$ & 1.7 & 1.9 & 0.07 & 0.01 \\
\hline 0 to $56 \mathrm{~d}$ & 1.8 & 1.9 & 0.03 & 0.02 \\
\hline \multicolumn{5}{|l|}{ Abnormal fecal score ${ }^{2}$ days, no. } \\
\hline 0 to $42 \mathrm{~d}$ & 0.3 & 0.4 & 0.24 & 0.77 \\
\hline 42 to $56 \mathrm{~d}$ & 0.0 & 0.0 & 0.04 & 1.00 \\
\hline 0 to $56 \mathrm{~d}$ & 0.3 & 0.4 & 0.23 & 0.76 \\
\hline Initial $\mathrm{BCS}^{3}$ & 2.3 & 2.2 & 0.04 & 0.04 \\
\hline \multicolumn{5}{|l|}{ Body condition change } \\
\hline 0 to $42 \mathrm{~d}$ & 0.2 & 0.4 & 0.05 & 0.10 \\
\hline 42 to $56 \mathrm{~d}$ & 0.1 & 0.0 & 0.05 & 0.16 \\
\hline 0 to $56 \mathrm{~d}$ & 0.3 & 0.3 & 0.06 & 0.77 \\
\hline Initial hip width, cm & 18.4 & 17.8 & 0.30 & 0.17 \\
\hline \multicolumn{5}{|l|}{ Hip width change, $\mathrm{cm}$} \\
\hline 0 to $42 \mathrm{~d}$ & 3.2 & 3.5 & 0.19 & 0.03 \\
\hline 42 to $56 \mathrm{~d}$ & 1.6 & 1.4 & 0.19 & 0.14 \\
\hline 0 to $56 \mathrm{~d}$ & 4.8 & 4.9 & 0.23 & 0.16 \\
\hline
\end{tabular}

${ }^{1}$ Citric acid was not accounted in this table. Average used $44 \mathrm{~g}$ per 1,000 g of milk replacer.

${ }^{2}$ Fecal scores were assigned daily based on a 1 to 5 system $(1=$ normal, thick in consistency; $2=$ normal, but less thick; $3=$ abnormally thin but not watery; $4=$ watery; $5=$ watery with abnormal coloring.

${ }^{3}$ Scores: 1 to 5 point system $(1=$ thin, 5 = obese $)$. 
Reconstituted MR was weighed before feeding and after the 2 -h period. From d 22 to 42 these calves were fed the same MR and amount as the control. Similar to R5 calves, A5 calves were fed $\mathrm{pH} 5.2 \mathrm{MR}$, but feed was offered ad libitum for d 0 to 35; from d 36 to 42 these calves were fed as the control. treatment A4 calves were fed the same MR solution as CON, but acidified to $\mathrm{pH}$ 4.2. This liquid solution was cooled to $32^{\circ} \mathrm{C}$ and citric acid powder was stirred in slowly to reach the target $\mathrm{pH}$ of 4.2. The acidified MR was set in a covered container at $21^{\circ} \mathrm{C}$ for $24 \mathrm{~h}$ before being fed to allow the liquid to become homogenous before feeding (Anderson, 2006). It was agitated by hand with a whisk for approximately $60 \mathrm{~s}$ at 0800,1200 , and $1800 \mathrm{~h}$ immediately before feeding. To feed, the reconstituted acidified MR was reheated to 45 to $46^{\circ} \mathrm{C}$ in a double water bath. Calves fed acidified MR had unconsumed MR weighed and new MR fed weighed at 0600, 0800, 1200, 1600, and 1800 h daily on d 0 to 35 for the ad libitum MR portion of the trial. From d 36 to 42, calves were fed MR without acidification as control. Calves were completely weaned by d 42 by only feeding MR at $0600 \mathrm{~h}$ on $\mathrm{d} 40,41$, and 42. Calves were fed starter (same as in trial 1) and water ad libitum. Statistical analysis was as described in trial 1. The 4 treatment means were separated using 3 preplanned contrast statements ( $\mathrm{CON}$ vs. $\mathrm{A} 5$ and $\mathrm{A} 4$; R5 vs. A5; A5 vs. A4).

\section{Trial 2a}

To assess the effect of $4 \mathrm{MR}$ programs on subsequent growth post-weaning, calves from trial 2 were moved to multi-calf pens on d 56 with calves grouped 4 per pen. Calves were grouped by MR treatments. Measurements were the same as in trial 1a. The trial lasted $56 \mathrm{~d}$ and was conducted during the months of March through May. Average ambient temperature during the trial was $15^{\circ} \mathrm{C}$ and ranged from 0 to $32^{\circ} \mathrm{C}$, based on hourly measurements. Average humidity was $65 \%$ and ranged from 20 to $94 \%$. Statistical analysis was as described in trial 1a. treatment means were separated using 3 preplanned contrast statements (CON vs. A5 and A4; R5 vs. A5; A5 vs. A4).

\section{RESULTS}

In each trial, control calves consumed all MR offered. The temperature of the acidified MR on offer exceeded $21^{\circ} \mathrm{C}$ between 0600 and $1800 \mathrm{~h}$ but frequently was as low as $15^{\circ} \mathrm{C}$, and occasionally as low as $10^{\circ} \mathrm{C}$ at $0600 \mathrm{~h}$ after sitting overnight. Initial measurements of calves in each trial did not differ among treatments.

\section{Trial 1}

One calf fed A4 refused to drink any MR during the first 2 meals and was removed from the trial. Intake of $\mathrm{MR}$ was greater $(P<0.05)$ for calves fed A4 ad libitum than the calves fed control MR $(0.657$ vs. $0.951 \mathrm{~kg} / \mathrm{d}$; Table 2). Whereas calves fed A4 has access to milk 24 h/day to $35 \mathrm{~d}$, they consumed $97.3 \%$ of the total day's intake between 0600 to $0800 \mathrm{~h}(53.5 \%)$ and 1600 to 1800 h (43.8\%; Table 3). Starter intake did not differ $(P>0.05)$ between treatments. Calves fed CON had lower ADG $(P<0.05)$ from d 0 to 42 but greater ADG $(P<0.05)$ from d 42 to 56 than calves fed A4, and tended to have a lower overall ADG $(P<0.10)$. Feed efficiency was greater $(P<0.05)$ for calves fed CON compared with calves fed A4 from d 42 to 56. Change in hip widths were greater $(P<0.05)$ and change in BCS tended $(P<0.10)$ to be greater in calves fed A4 compared with CON from d 0 to 42 . Days with abnormal fecal scores and medical treatment did not differ between treatments; however, calves fed A4 had greater fecal scores (looser feces; $P<0.05$ ) from d 42 to 56 than calves fed CON.

Standing behavior was monitored from d 6 to 56 (Table 4). During d 6 to 35, when the MR treatments were applied, total time spent standing did not differ between treatments $(P>0.26 ; 342 \mathrm{~min}$ for CON, 315 min for A4; $23 \%$ of the day), but CON cows spent approximately 30 more min standing between 1200 and

Table 3. Percentage of acidified milk replacers consumed during different time periods of the day when fed ad libitum during trials 1 and 2

\begin{tabular}{lcccc}
\hline Time period $^{1}$ & $\begin{array}{c}\text { Length of } \\
\text { period, h }\end{array}$ & $\begin{array}{c}\text { Trial 1, } \\
\mathrm{pH} 4.2\end{array}$ & $\begin{array}{c}\text { Trial 2, } \\
\mathrm{pH} 5.2\end{array}$ & $\begin{array}{c}\text { Trial 2, } \\
\mathrm{pH} \mathrm{4.2}\end{array}$ \\
\hline 0600 to $0800 \mathrm{~h}$ & 2 & 53.5 & 49.9 & 51.3 \\
0800 to $1200 \mathrm{~h}$ & 4 & 1.1 & 2.9 & 1.9 \\
1200 to $1600 \mathrm{~h}$ & 4 & 0.3 & 0.5 & 0.2 \\
1600 to $1800 \mathrm{~h}$ & 2 & 43.8 & 45.6 & 45.9 \\
1800 to $0600 \mathrm{~h}$ & 12 & 1.3 & 1.1 & 0.7 \\
SEM & - & 4.27 & 1.94 & 3.84 \\
\hline
\end{tabular}

${ }^{1}$ Data presented as percent of daily milk replacer consumed. 
Table 4. Standing time ( $\mathrm{min})$ of calves fed a control milk replacer at a fixed rate (CON) or a milk replacer acidified to $\mathrm{pH} 4.2$ and fed ad libitum between d 6 and 35 (A4) in trial 1

\begin{tabular}{lccrrc}
\hline Time period & $\begin{array}{c}\text { Length of } \\
\text { period, } \mathrm{h}\end{array}$ & CON & A4 & SEM & $P$-value \\
\hline 0600 to $0800 \mathrm{~h}$ & 2 & 63 & 50 & 8.8 & 0.15 \\
0800 to $1200 \mathrm{~h}$ & 4 & 73 & 74 & 9.9 & 0.93 \\
1200 to $1600 \mathrm{~h}$ & 4 & 104 & 72 & 11.8 & 0.03 \\
1600 to $1800 \mathrm{~h}$ & 2 & 26 & 36 & 5.2 & 0.10 \\
1800 to $0600 \mathrm{~h}$ & 12 & 75 & 83 & 11.9 & 0.53 \\
Total day & 24 & 342 & 315 & 41.7 & 0.54 \\
\% of total day & - & 24 & 22 & - & - \\
\hline
\end{tabular}

$1600 \mathrm{~h}(P<0.03 ; 104$ vs. $72 \mathrm{~min})$. Total standing time increased over the trial (d 6 to $56 ; P<0.03$ ) by only 20 $\min$ (312 to $332 \mathrm{~min} ; 21.6$ to $23.0 \%$ of the day).

\section{Trial 1a}

Calves previously fed CON had greater $(P<0.05)$ change in hip widths from d 56 to 112 than calves previously fed A4 (Table 5 ). Calf DM intake over the 56 -d trial averaged $3.5 \mathrm{~kg}$ of $\mathrm{DM} / \mathrm{d}$, or $3.1 \%$ of $\mathrm{BW}$. Otherwise no differences in calf performance were observed.

\section{Trial 2}

Two calves fed A4 refused to drink any MR during the first 2 meals and were removed from the trial. Intake of MR among the 4 treatments ranked A5 > A4 $>\mathrm{R} 5>\mathrm{CON}$ (Table 6 ). Intake of MR by week among the 4 treatments is shown in Figure 1. The $2 \mathrm{pH} 5.2$ treatments (R5 and A5) were evaluated because of feed refusals when calves were offered $\mathrm{MR}$ at $\mathrm{pH} 4.2 \mathrm{MR}$ in trial 1; our data suggest that $\mathrm{pH} 4.2$ is marginally palatable. Whereas calves fed A5 and A4 were offered $\mathrm{MR}$ ad libitum from d 0 to 35 , they consumed $>95 \%$ of the total day's intake between 0600 to $0800 \mathrm{~h}$ and 1600 to $1800 \mathrm{~h}$ (Table 3). Variability of MR intake was large for R5, A5, and A4 (Table 7), and appeared to decrease in wk 4 and 5 with calves fed A5 versus A4. Starter intake did not differ among the treatments. From d 0 to 42, ADG was less $(P<0.05)$ for calves fed CON versus $\mathrm{A} 5$ and $\mathrm{A} 4$, and greater $(P<0.05)$ for calves fed R5 versus A5. From d 42 to 56 , ADG was less $(P<0.05)$ for calves fed A5 and A4 versus CON, and greater $(P$ $<0.05)$ for calves fed R5 versus A5. From d 0 to 56, ADG tended $(P<0.10)$ to be less for calves fed CON versus $\mathrm{A} 4$ and $\mathrm{A} 5$, and tended $(P<0.10)$ to be greater for calves fed A5 versus A4. From d 42 to 56, feed efficiency was greater $(P<0.05)$ for calves fed CON versus $\mathrm{A} 5$ and $\mathrm{A} 4$, and tended $(P<0.10)$ to be greater for calves fed A4 versus A5. Some differences in hip width changes were noted during d 0 to 42 and d 42 to 56 , however, overall (d 0 to 56) no differences were ob-

Table 5. Performance of calves previously fed a control milk replacer at a fixed rate (CON) or a milk replacer acidified to $\mathrm{pH} 4.2$ and fed ad libitum (A4) in trial 1a

\begin{tabular}{lcccc}
\hline Item & CON & A4 & SEM & $P$-value \\
\hline Calves, no. & 10 & 9 & & \\
Initial BW, kg & 80.4 & 84.0 & 3.13 & 0.41 \\
Final BW, kg & 148.9 & 150.3 & 5.35 & 0.85 \\
Initial hip width, cm & 10.2 & 10.5 & 0.14 & 0.19 \\
Final hip width, cm & 13.0 & 12.9 & 0.14 & 0.74 \\
Initial BCS & 2.6 & 2.5 & 0.83 & 0.17 \\
Final BCS & 3.1 & 2.9 & 0.82 & 0.79 \\
ADG, kg/d & 0.922 & & & 0.41 \\
56 to 84 d & 1.525 & 1.411 & 0.0900 & 0.57 \\
84 to 112 d & 1.224 & 1.183 & 0.0491 & 0.17 \\
56 to 112 d & & & & 0.62 \\
Hip width, cm & 2.5 & 2.0 & 0.28 & 0.01 \\
56 to 84 d change & 3.5 & 3.3 & 0.25 & 0.19 \\
84 to 112 d change & 6.0 & 5.3 & & 0.38 \\
56 to 112 d change & & & 0.071 & 0.27 \\
BCS ${ }^{1}$ to 84 d change & 0.1 & 0.1 & 0.3 & \\
84 to 112 d change & 0.4 & 0.5 & 0.4 & \\
56 to 112 d change & 0.5 & & & \\
\hline
\end{tabular}

${ }^{1}$ Scores: 1 to 5 point system $(1=$ thin, $5=$ obese $)$. 
Table 6. Performance of calves fed a control milk replacer at a fixed rate (CON), a milk replacer acidified to $\mathrm{pH} 5.2$ and fed ad libitum during 2-h time periods in the a.m. and p.m. (R5), a milk replacer acidified to $\mathrm{pH} 5.2$ and fed ad libitum (A5), and a milk replacer acidified to pH 4.2 and fed ad libitum (A4) in trial 2

\begin{tabular}{|c|c|c|c|c|c|c|c|c|c|}
\hline Item & $\mathrm{CON}$ & R5 & A5 & A4 & SEM & \multicolumn{3}{|c|}{ Preplanned contrast $P$-value } & $\begin{array}{l}\text { Overall } \\
P \text {-value }\end{array}$ \\
\hline Initial serum protein, $\mathrm{mg} / \mathrm{dL}$ & 5.0 & 5.0 & 5.0 & 5.1 & 0.19 & 0.73 & 0.88 & 0.76 & 0.96 \\
\hline \multirow{2}{*}{\multicolumn{10}{|c|}{$\mathrm{ADG}, \mathrm{kg} / \mathrm{d}$}} \\
\hline & & & & & & & & & \\
\hline \multicolumn{10}{|l|}{ Milk replacer intake ${ }^{1}$} \\
\hline $\mathrm{kg} / \mathrm{d}, 0$ to $42 \mathrm{~d}$ & 0.632 & 0.790 & 0.968 & 0.863 & 0.0277 & 0.001 & 0.001 & 0.01 & 0.001 \\
\hline Total $\mathrm{kg}, 0$ to $42 \mathrm{~d}$ & 26.6 & 33.2 & 40.7 & 36.3 & 1.16 & 0.001 & 0.001 & 0.01 & 0.001 \\
\hline \multicolumn{10}{|l|}{ Starter intake, $\mathrm{kg} / \mathrm{d}$} \\
\hline 0 to $42 \mathrm{~d}$ & 0.269 & 0.294 & 0.218 & 0.237 & 0.0360 & 0.93 & 0.09 & 0.71 & 0.34 \\
\hline 42 to $56 \mathrm{~d}$ & 1.803 & 2.012 & 2.024 & 1.834 & 0.1448 & 0.45 & 0.94 & 0.33 & 0.49 \\
\hline \multicolumn{10}{|l|}{ Feed efficiency, gain/feed } \\
\hline \multicolumn{10}{|l|}{ Medical days, no. } \\
\hline 0 to $42 \mathrm{~d}$ & 2.1 & 3.0 & 3.8 & 3.0 & 0.60 & 0.17 & 0.31 & 0.35 & 0.18 \\
\hline 42 to $56 \mathrm{~d}$ & 0.7 & 0.5 & 0.3 & 0.6 & 0.28 & 0.65 & 0.46 & 0.41 & 0.66 \\
\hline \multirow{2}{*}{\multicolumn{10}{|c|}{ Fecal score ${ }^{2}$}} \\
\hline & & & & & & & & & \\
\hline 0 to $42 \mathrm{~d}$ & 1.9 & 2.1 & 2.0 & 2.0 & 0.05 & 0.15 & 0.76 & 0.39 & 0.22 \\
\hline 42 to $56 \mathrm{~d}$ & 1.9 & 2.0 & 2.0 & 1.8 & 0.06 & 0.52 & 0.82 & 0.06 & 0.13 \\
\hline 0 to $56 \mathrm{~d}$ & 1.9 & 2.0 & 2.0 & 1.9 & 0.05 & 0.14 & 0.85 & 0.17 & 0.09 \\
\hline \multicolumn{10}{|l|}{ Abnormal fecal score ${ }^{2}$ days, no. } \\
\hline 0 to $42 \mathrm{~d}$ & 0.5 & 1.7 & 1.6 & 0.7 & 0.43 & 0.16 & 0.88 & 0.12 & 0.07 \\
\hline 42 to $56 \mathrm{~d}$ & 0.3 & 0.7 & 0.7 & 0.2 & 0.27 & 0.71 & 1.00 & 0.23 & 0.48 \\
\hline 0 to $56 \mathrm{~d}$ & 0.8 & 2.3 & 2.3 & 0.9 & 0.59 & 0.23 & 0.91 & 0.09 & 0.07 \\
\hline Initial $\mathrm{BCS}^{3}$ & 2.2 & 2.3 & 2.2 & 2.2 & 0.04 & 0.34 & 0.02 & 0.77 & 0.10 \\
\hline \multicolumn{10}{|l|}{ BCS change } \\
\hline \multicolumn{10}{|l|}{ Hip width change, $\mathrm{cm}$} \\
\hline
\end{tabular}

${ }^{1}$ Citric acid was not accounted in this table. Average used was 12 and $44 \mathrm{~g}$ per 1,000 $\mathrm{g}$ of milk replacer for $\mathrm{pH} 5.2$ and 4.2 , respectively.

${ }^{2}$ Fecal scores were assigned daily based on a 1 to 5 system $(1=$ normal, thick in consistency; $2=$ normal, but less thick; $3=$ abnormally thin but not watery; $4=$ watery; $5=$ watery with abnormal coloring).

${ }^{3}$ Scores: 1 to 5 point system $(1=$ thin, $5=$ obese $)$.

served. No differences among treatments in days with abnormal fecal scores, medical treatments, or average fecal scores were observed.

\section{Trial 2a}

From d 56 to 112, calves on CON had a greater ADG $(P<0.05)$ than calves on $\mathrm{A} 5$ and $\mathrm{A} 4$, whereas calves on R5 had a greater ADG $(P<0.05)$ than calves on A5 (Table 8). Intake did not differ $(P<0.05)$ among treatments. From d 56 to 112 , calves on CON had greater feed efficiency $(P<0.05)$ than calves on A5 and A4, whereas calves on R5 had greater feed efficiency $(P<$ 0.05) than calves on A5. From d 56 to 112, calves on CON had greater change in hip width $(P<0.05)$ than calves on A5 and A4, whereas calves on R5 had greater change in hip width $(P<0.05)$ than calves on A5.

\section{DISCUSSION}

Intake of $\mathrm{pH} 4.2 \mathrm{MR}$ was a concern in these trials, with 3 of 22 calves refusing to drink any MR and with 


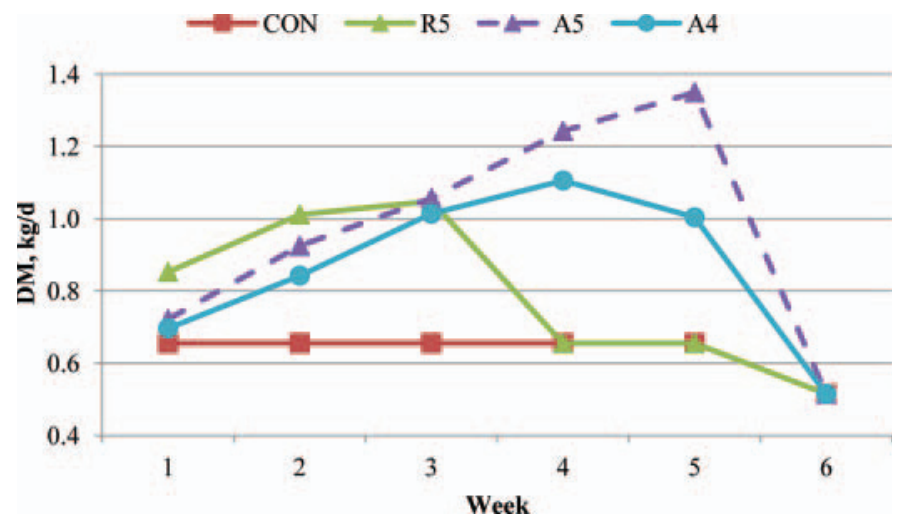

Figure 1. Intake of milk replacer by week by calves fed a control milk replacer at a fixed rate $(\mathrm{CON})$, a milk replacer acidified to $\mathrm{pH}$ 5.2 and fed ad libitum during 2 -h periods in the a.m. and p.m. (R5), a milk replacer acidified to $\mathrm{pH} 5.2$ and fed ad libitum (A5), and a milk replacer acidified to $\mathrm{pH} 4.2$ and fed ad libitum (A4) in trial 2. Treatments CON and R5 were fed at the same fixed rate during wk 4 and 5. During wk 6, all calves were fed the same fixed rate of milk replacer. Variation reported in Table 7 . Color version available in the online PDF.

intake of $\mathrm{pH} 4.2 \mathrm{MR}$ being less than intake of $\mathrm{pH} 5.2$ $\mathrm{MR}$ in trial 2. This related to less preweaning ADG in trial 2 with calves fed A4 versus A5. Others that have acidified milk replacer generally have maintained $\mathrm{pH}$ at or above 5.2 (Bush and Nicholson, 1987; Fallon and Harte, 1988; Woodford et al., 1987). Digestion in calves only fed MR was unaffected with acidification to $\mathrm{pH}$ 5.3 (Woodford et al., 1987).

It was interesting that $>95 \%$ of the MR consumed by calves fed ad libitum was consumed during the 2 -h intervals during the a.m. and p.m., despite those cows having the opportunity to consume MR $24 \mathrm{~h}$ per day. This is somewhat consistent with results reported by von Keyserlingk et al. (2006). Whereas they did not measure intake over different hours of the day, they measured time spent on the nipple of pails. The majority of time on the nipples was around the $2 \mathrm{~h}$ of milk feeding in the a.m. and p.m. for both calves fed milk during this restricted time period and calves fed ad libitum 24-h daily. Milk intake, starter intake, and ADG did not differ between their treatment groups.

The pattern in MR intake increasing over time for the different treatments (Figure 1) has been reported in experiments where milk was delivered using automated feeders. Borderas et al. (2009) and de Passillé et al. (2011) reported a substantial increase in milk intake as the calf aged, similar to what we observed. Conversely, Jensen (2006) reported little increase in milk consumption with increasing age in 3 different breeds. Jensen (2006) did cap intake, however, preventing a large increase in milk consumed. Many of their calves appeared not to consume the maximum allowed intake (7.2 to $9.6 \mathrm{~L} / \mathrm{d}$ depending upon breed) even after $42 \mathrm{~d}$ on the nipple (calves $\geq 54 \mathrm{~d}$ of age).

In trial 1, where standing time was measured, only minor differences were noted between MR treatments. Minutes standing per day only increased by $20 \mathrm{~min}$ (312 to $332 \mathrm{~min}$ ) from d 6 to 56 , when measurements were made. Panivivat et al. (2004) reported similar standing times as we observed, however, as their calves aged from 1 to $6 \mathrm{wk}$, time standing increased by approximately $110 \mathrm{~min} / \mathrm{d}$. Camiloti et al. (2012) reported approximately $100 \mathrm{~min} / \mathrm{d}$ more standing time than we observed.

As in trials 2 and 2a, where ADG was increased over CON preweaning but decreased versus CON postweaning with A5 and A4, others have reported this in calves fed milk (Bar-Peled et al., 1997; Jasper and Weary, 2002) and calves fed unacidified MR (Cowles et al.,

Table 7. Minimum and maximum intake of milk replacer and CV by week for calves fed a control milk replacer at a fixed rate (CON), a milk replacer acidified to $\mathrm{pH} 5.2$ and fed ad libitum during 2-h time periods in the a.m. and p.m. (R5), a milk replacer acidified to $\mathrm{pH} 5.2$ and fed ad libitum (A5), and a milk replacer acidified to $\mathrm{pH} 4.2$ and fed ad libitum (A4) in trial 2

\begin{tabular}{|c|c|c|c|c|c|}
\hline Treatment & Wk 1 & Wk 2 & Wk 3 & Wk 4 & Wk 5 \\
\hline \multicolumn{6}{|c|}{ Minimum, $\mathrm{kg}$ of $\mathrm{DM} / \mathrm{d}$} \\
\hline $\mathrm{CON}$ & 0.655 & 0.655 & 0.655 & 0.655 & 0.655 \\
\hline R5 & 0.587 & 0.664 & 0.770 & 0.655 & 0.655 \\
\hline A5 & 0.433 & 0.510 & 0.645 & 1.059 & 1.059 \\
\hline A4 & 0.414 & 0.626 & 0.770 & 0.742 & 0.684 \\
\hline \multicolumn{6}{|c|}{ Maximum, $\mathrm{kg}$ of $\mathrm{DM} / \mathrm{d}$} \\
\hline CON & 0.655 & 0.655 & 0.655 & 0.655 & 0.655 \\
\hline R5 & 1.165 & 1.271 & 1.290 & 0.655 & 0.655 \\
\hline A5 & 1.040 & 1.233 & 1.242 & 1.348 & 1.445 \\
\hline A4 & 1.098 & 0.973 & 1.233 & 1.483 & 1.608 \\
\hline \multicolumn{6}{|l|}{$\mathrm{CV}, \%$} \\
\hline $\mathrm{CON}$ & - & - & - & - & - \\
\hline R5 & 23.2 & 23.5 & 15.4 & - & - \\
\hline A5 & 22.1 & 22.2 & 15.5 & 8.5 & 9.2 \\
\hline A4 & 34.6 & 24.6 & 16.6 & 19.9 & 27.7 \\
\hline
\end{tabular}


Table 8. Performance of calves previously fed a control milk replacer at a fixed rate (CON), a milk replacer acidified to $\mathrm{pH} 5.2$ and fed ad libitum during 2-h time periods in the a.m. and p.m. (R5), a milk replacer acidified to $\mathrm{pH} 5.2$ and fed ad libitum (A5), and a milk replacer acidified to $\mathrm{pH} 4.2$ and fed ad libitum (A4) in trial 2a

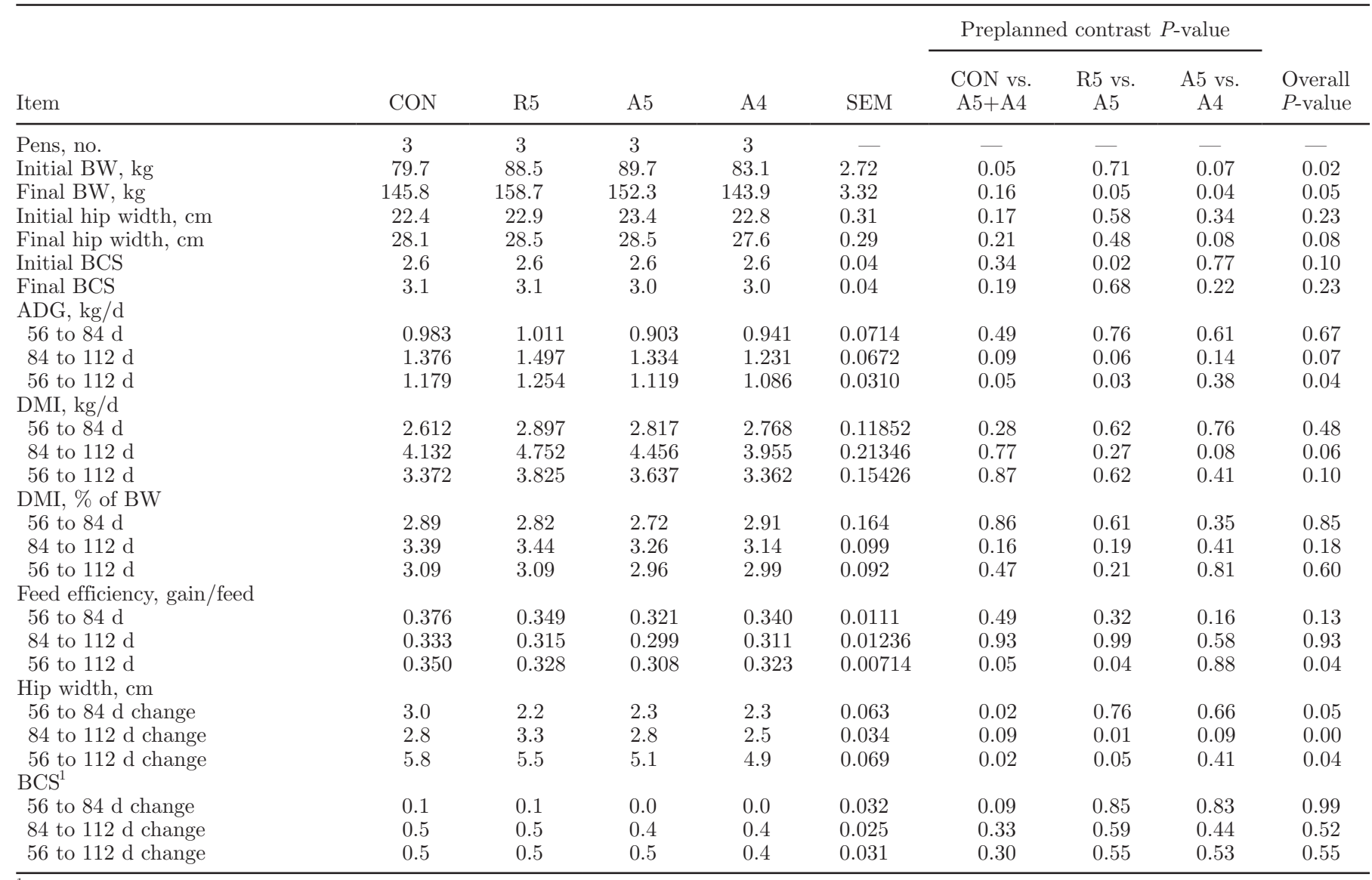

${ }^{1}$ Scores: 1 to 5 point system $(1=$ thin, $5=$ obese $)$.

2006; Hill et al., 2006) or acidified MR (Nocek and Braund, 1986; Hepola et al., 2008). In addition, Hepola et al. (2008) reported that calves fed an acidified MR for ad libitum consumption consumed very little water, which could exacerbate limited starter intake and further delay rumen development. Two laboratories have reported 6 to $9 \%$ lower digestion postweaning in calves fed high versus low amounts of MR (Terré et al., 2006, 2007; Hill et al., 2012). The low digestion in calves fed high levels of MR was associated with less development of the rumen (Terré et al., 2006, 2007; Suarez-Mena et al., 2011). Reduced ADG in the weaning and postweaning periods from feeding large amounts of milk or MR has been overcome by gradually weaning calves over 14 to 25 d (Khan et al., 2007; Hill et al., 2007, 2012; Sweeney et al., 2010); thus providing a reason for implementing R5 in trial 2 . Gradual weaning by reducing MR fed at d 21 in R5 reduced preweaning ADG compared with A5 and A4, but increased postweaning ADG, resulting in no difference in 0 to $56 \mathrm{~d}$ ADG. Ad- ditionally, ADG from d 56 to 112 in trial 2a was greater in calves managed on $\mathrm{R} 5$ versus $\mathrm{A} 5$.

For trial 2, total BW gain (0 to 112 d) was 104, 111, 106 , and $101 \mathrm{~kg}$ for CON, R5, A5, and A4, respectively. Total DM consumed was 258, 296, 289, and $268 \mathrm{~kg}$ for CON, R5, A5, and A4, respectively. Overall feed efficiency (gain:feed) was $0.40,0.38,0.37$, and 0.38 for $\mathrm{CON}, \mathrm{R} 5$, A5, and A4, respectively. Because the experimental unit changed from individual calf during the first $56 \mathrm{~d}$ to pen of 4 calves during the last $56 \mathrm{~d}$, statistical analyses of these data were not performed. Only R5, pH 5.2 MR fed ad libitum for $21 \mathrm{~d}$ before feeding at fixed rate of $0.68 \mathrm{~kg}$ of MR powder until weaning at $42 \mathrm{~d}$, yielded any trends for BW gain advantage over $\mathrm{CON}$. Because of the lower intake of MR and its higher cost versus starter and hay, feed costs and cost per unit BW gain should be lowest in most US market situations for calves fed the control. Use of nonsaleable milk that has a low value could change this economic assumption if ADG was not reduced versus the current results. 


\section{CONCLUSIONS}

Under the conditions of these trials, results to $112 \mathrm{~d}$ showed no advantage to feed MR acidified to $\mathrm{pH} 4.2$ or 5.2 ad libitum from 0 to $35 \mathrm{~d}$ and then gradually wean by $42 \mathrm{~d}$ compared with the control MR fed at $0.66 \mathrm{~kg}$ of $\mathrm{DM} / \mathrm{d}$. Acidification to $\mathrm{pH} 4.2$ versus 5.2 resulted in some calves refusing to drink the MR and less total MR consumption. Additionally, when calves were fed MR ad libitum, they consumed $>95 \%$ of the MR between 0600 to $0800 \mathrm{~h}$ and 1600 to $1800 \mathrm{~h}$ and standing behavior was not greatly altered versus control calves.

\section{REFERENCES}

Anderson, N. 2006. Mimicking nature's way for milk-fed dairy calves: Free-access feeding with acidified milk. Ontario Ministry of Agriculture, Food, and Rural Affairs. Accessed Jul. 24, 2012. http:// www.omafra.gov.on.ca/english/livestock/dairy/facts/mimick.htm.

AOAC International. 2000. Official Methods of Analysis. Vol. I. 17th ed. AOAC International, Arlington, VA.

Bar-Peled, U., B. Robinzon, E. Maltz, H. Tagari, Y. Folman, I. Bruckental, H. Voet, H. Gacitua, and A. R. Lehrer. 1997. Increased weight gain and effects on production parameters of Holstein heifer calves that were allowed to suckle from birth to six weeks of age. J. Dairy Sci. 80:2523-2528.

Borderas, T. F., A. M. de Passille, and J. Rushen. 2009. Feeding behavior of calves fed small or large amounts of milk. J. Dairy Sci 92:2843-2852.

Bush, R. S., and J. W. G. Nicholson. 1987. Effect of two acids and formalin in calves milk on feed consumption and performance. Can. J. Anim. Sci. 67:1129-1131.

Camiloti, T. V., J. A. Fregonesi, M. A. G. von Keyserlingk, and D. M. Weary. 2012. Short communication: Effects of bedding quality on the lying behavior of dairy calves. J. Dairy Sci. 95:3380-3383.

Conway, J. 2011. Serious growth, comfort and socialization-The "herd calf" thrives in ad-lib fed group housing. PRO-DAIRY Cornell University. Accessed Jul. 24, 2012. http://www.ansci.cornell. edu/prodairy/calfsystems/groupcalfarticle2.pdf.

Cowles, K. E., R. A. White, N. L. Whitehouse, and P. S. Erickson. 2006. Growth characteristics of calves fed an intensified milk replacer regime with additional lactoferrin. J. Dairy Sci. 89:48354845.

de Passillé, A. M., T. F. Borderas, and J. Rushen. 2011. Weaning age of calves fed a high milk allowance by automated feeders: Effects on feed, water, and energy intake, behavioral signs of hunger, and weight gains. J. Dairy Sci. 94:1401-1408.

De Paula Vieira, A., M. A. G. von Keyserlingk, and D. M. Weary. 2010. Effects of pair versus single housing on performance and behavior of dairy calves before and after weaning from milk. J. Dairy Sci. 93:3079-3085.

Fallon, R. J., and F. J. Harte. 1988. Effect of normal or acidified milk replacer offered ad libitum on calf performance. Isr. J. Agric. Res. $27: 123-130$.

FASS. 2010. Guide for the Care and Use of Agricultural Animals in Agricultural Research and Teaching. 3rd ed. Federation of Animal Science Societies, Champaign, IL.

Hepola, H. P., L. T. Hanninen, S. M. Raussi, P. A. Pursiainen, A.-M. Aarnikoivu, and H. S. Saloniemi. 2008. Effects of providing water from a bucket or a nipple on the performance and behavior of calves fed ad libitum volumes of acidified milk replacer. J. Dairy Sci. 91:1486-1496.

Hill, T. M., J. M. Aldrich, R. L. Schlotterbeck, and H. G. Bateman II.. 2006. Effects of feeding calves different rates and protein concentrations of twenty percent fat milk replacers on growth during the neonatal period. Prof. Anim. Sci. 22:252-260.
Hill, T. M., H. G. Bateman II, J. M. Aldrich, and R. L. Schlotterbeck. 2007. Effects of feeding rate of milk replacers and bedding material for calves in a cold naturally ventilated nursery. Prof. Anim. Sci. 23:656-664.

Hill, T. M., H. G. Bateman II, J. M. Aldrich, and R. L. Schlotterbeck. 2012. Methods of reducing milk replacer to prepare dairy calves for weaning when large amounts of milk replacer have been fed. Prof. Anim. Sci. 28:332-337.

Ito, K., D. M. Weary, and M. A. G. von Keyserlingk. 2009. Lying behavior: Assessing within- and between herd variation in free-stallhoused dairy cows. J. Dairy Sci. 92:4412-4420.

Jasper, J., and D. M. Weary. 2002. Effects of ad-libitum milk intake on dairy calves. J. Dairy Sci. 85:3054-3058.

Jensen, M. B. 2006. Computer-controlled milk feeding of group-housed calves, the effect of milk allowance and weaning type. J. Dairy Sci. 89:201-206.

Kertz, A. F., and H. Chester-Jones. 2004. Invited review: Guidelines for measuring and reporting calf and heifer experimental data. J. Dairy Sci. 87:3577-3580.

Khan, M. A., H. J. Lee, W. S. Lee, H. S. Kim, S. B. Kim, K. S. Ki, J. K. Ha, H. G. Lee, and Y. J. Choi. 2007. Pre- and postweaning performance of Holstein female calves fed milk through step-down and conventional methods. J. Dairy Sci. 90:876-885.

Nocek, J. E., and D. G. Braund. 1986. Performance, health, and postweaning growth on calves fed cold, acidified milk replacer ad libitum. J. Dairy Sci. 69:1877-1883.

Panivivat, R., E. B. Kegley, J. A. Pennington, D. W. Kellogg, and S. L. Krumpelman. 2004. Growth performance and health of dairy calves bedded with different types of materials. J. Dairy Sci. $87: 3736-3745$.

Richard, A. L., A. J. Heinrichs, and L. D. Muller. 1988. Feeding acidified milk replacer ad libitum to calves housed in group versus individual pens. J. Dairy Sci. 71:2203-2209.

Robertson, J. B., and P. J. Van Soest. 1981. The Detergent System of Analysis and its Application to Human Foods. Cornell University, Ithaca, NY.

Suarez-Mena, F. X., T. M. Hill, A. J. Heinrichs, H. G. Bateman II, J. M. Aldrich, and R. L. Schlotterbeck. 2011. Effects of including corn distillers dried grains with solubles in dairy calf feeds. J. Dairy Sci. 94:3037-3044.

Sweeney, B. C., J. Rushen, D. M. Weary, and A. M. de Passillé. 2010. Duration of weaning, starter intake, and weight gain of dairy calves fed large amounts of milk. J. Dairy Sci. 93:148-152.

Terré, M., M. Devant, and A. Bach. 2006. Performance and nitrogen metabolism of calves fed conventionally or following an enhancedgrowth feeding program during the preweaning period . Livest. Sci. 105:109-119.

Terré, M., M. Devant, and A. Bach. 2007. Effect of level of milk replacer fed to Holstein calves on performance during the preweaning period and starter digestibility at weaning. Livest. Sci. 110:82-88.

Thickett, W. W., N. H. Cuthbert, T. D. A. Brigstocke, M. A. Lindeman, and P. N. Wilson. 1983. A note on the performance and management of calves reared on cold acidified milk replacer fed ad libitum. Anim. Prod. 36:147-150.

Van Soest, P. J., J. B. Robertson, and B. A. Lewis. 1991. Methods for dietary fiber, neutral detergent fiber, and nonstarch polysaccharides in relation to animal nutrition. J. Dairy Sci. 74:3583-3597.

von Keyserlingk, M. A. G., F. Wolf, M. Hotzel, and D. M. Weary. 2006 Effects of continuous versus periodic milk availability on behavior and performance of daily calves. J. Dairy Sci. 89:2126-2131.

Wildman, E. E., G. M. Jones, P. E. Wagner, R. L. Bowman, H. F. Troutt Jr., and T. N. Lesch. 1982. A dairy cow body condition scoring system and its relationship to selected production characteristics. J. Dairy Sci. 65:495-501.

Woodford, S. T., H. D. Whetstone, M. R. Murphy, and C. L. Davis 1988. Abomasal $\mathrm{pH}$, nutrient digestibility, and growth of Holstein bull calves fed acidified milk replacer. J. Dairy Sci. 70:888-891. 